\title{
PIDANA MATI TERHADAP TINDAK PIDANA KORUPSI DIMASA PANDEMI COVID 19
}

\author{
Ook Mufrohim, Imam Subaweh, Joko Setiyono \\ Fakultas Hukum Universitas Diponegoro, \\ J1. Prof. Sudarto No.13, Tembalang, Kec. Tembalang, Kota Semarang, Jawa Tengah \\ Email: mufrohimook@gmail.com,Imamsubaweharifin6@gmail.com, \\ jokosetiyono1961@gmail.com
}

\begin{abstract}
ABSTRAK
Tindak Pidana Korupsi di Indonesia bukan sesuatu hal yang baru, melainkan merupakan kejahatan lama yang sudah sering terjadi, di dalam Undang-undang Nomor 31 tahun 1999 tentang Pemberantasan Tindak Pidana Korupsi, terdapat alasan limitatif yang menyebabkan tindak pidana korupsi di Indonesia tidak serta merta dapat di tajatuhi pidana mati, alasan tersebut dijadikan alasan pemberat sehingga tindak pidana korupsi dapat di jatuhi pidana mati. Dengan demikian maka Tindak pidana korupsi di Indonesia yang dilakukan pada masa Pandemi Covid-19 dapat dijatuhi Pidana mati dikarenakan Pandemi Covid 19 merupakan suatu keadaan bencana yang sedang terjadi di Indonesia bahkan di dunia. Demikian ini sesuai dengan penjelasan Pasal 2 Undang-undang nomor 31 tahun 1999 yang dapat melatarelakangi penjatuhan pidana mati bagi pelaku Tindak Pidana Korupsi di Indonesia. Penelitian ini bertujuan untuk mengetahui bahwa Pelaku Tindak Pidana Korupsi di masa Pandemi Covid 19 dapat dijatuhi pidana mati. Metode pendeketan yang digunakan dengan menggunakan pendekatan perundang-undangan. Hasil Penelitian ini menunjukkan bahwa hanya pelaku tindak pidana korupsi tertentu yang dapat dijerat dengan pidana mati.
\end{abstract}

Kata Kunci : Korupsi, Pandemi Covid-19, Pidana Mati

\begin{abstract}
Corruption in Indonesia is not something new, but an old crime that has often occurred, in Law Number 31 of 1999 concerning the Eradication of Corruption, there are reasons that limit corruption in Indonesia as a direct punishment for death penalty., this reason is used as an excuse to make a criminal act of corruption punishable. Thus, the criminal act of corruption in Indonesia carried out during the Covid-19 Pandemic can be sentenced to death because the Covid 19 Pandemic is a catastrophic disaster that occurred in Indonesia and even in the world. Thus, this is in accordance with the explanation of Article 2 of Law Number 31 of 1999 which can be the background for the imposition of crimes for perpetrators of Corruption in Indonesia. This study aims to see that the perpetrators of corruption during the Covid 19 pandemic can be sentenced to death. The approach method used is the invitation-approach approach. The results of this study indicate that a criminal act of corruption is punishable by death
\end{abstract}

Keywords: Corruption, Covid-19 Pandemic, Death Penalty 
A. Pendahuluan

Indonesia merupaka Negara hukum dimana tertulis di UndangUndang Dasar Negara Republik Indonesia 1945, maka sudah seharusnya hukum menjadi panglima tertingi. Perkembangan penegakan hukum di Indonesia harus menjadi perhatian bersama-sama, agar Negara Indonesia menajadi Negara berdaulat atas hukumnya sendiri, maka pelaku pelanggaran hukum harus mendapatkan sanksi yang membuat efek jera bagi pelaku.

Korupsi sudah sangat meluas secara sistemik merusak semua sector di berbagai tingkatan baik dari daerah hingga ke pusat, di semua lembaga baik di eksekutif, legislative maupun yudikatif. Maka sebab itu korupsi di golongkan sebagai kejahatan luar biasa (exta ordinary crime). Perkembangan Tindak Pidana di Indonesia semakin kompleks dan perlu untuk dilakukan upaya penegakan dan pencegahan agar tidak kejahatan di Indonesia tidak terus menerus mengalami peningkatan yang akan berakibat merugikan masyarakat maupun merugikan Negara. Kejahatan yang dilakukan yang sangat merugikan Negara diantaranya pelaku kejahatan Tindak Pidana Korupsi. Kejahatan Korupsi di Indonesia sendiri dari tahunketahun mengalami peningkatan yang signifikan, hal tersebut sesuai dari data pelaku kejahatan Korupsi yang di keluarkan oleh, Sepanjang tahun 2019, Komisi Pemberantasan Korupsi telah melakukan penyelidikan terhadap 142 kasus, melakukan penyidian 268 perkara, dan melakukan penuntutan terhadap 234 perkara ${ }^{1}$. Operasi Tangkap Tangan atau (OTT) sendiri yang dilakukan Komisi Pemberantasan Korupsi (KPK) telah dilakukan sebanyak 21 kali di 14 daerah dan menjerat 76 0rang dengan dengan

\footnotetext{
1 Laporan Komisi Pemberantasan Korupsi, sepanjang tahun 2019. 117
}

barang bukti berupa uang tunai dari berbagai mata uang. Serta sepanjang tahun 2019 terdapat 2 (dua) kasus yang sangat besar berupa penetapan Korporasi sebagai tersangka yaitu PT ME terkait Tindak pidana Korupsi suap terkait pembebasan dan pengesahan RKA-K/L dalam APBN-P TA 2016 untuuk bakamla RI dengan dugaan jumlah suap senilai USD 911.480 atau senilai (12 M Rupiah), dam kasus PT PS karena Tindak Pidana Korupsi Suap terkait pengajuan revisi alih fungsi hutan riau tahun 2014 kepada Kementrian Kehutanan (hasil pengembangan kasus Operasi Tangkap tangan Gubernur Riau Annas Maamun) dugaan suap senulai 3 Milliar Rupiah ${ }^{2}$. Corona virus (Covid-19) merupakan virus jenis terbaru yang diketahui manusia pertama kali di Wuhan China pada bulan desember tahun 2019, lalu dinamai sebagai Severe Acute Respiratory Syndrome Coronavirus 2 (SARS- COV2), mengakibatkan penyakit Coronavirus Disease-2019 (COVID-19). COVID19 merupakan genus dengan for elliptic dan sering berbentuk pleomorfk, dan berdiameter sangat kecil yakni hanya 60- $140 \mathrm{~nm}$. Virus ini secara genetik sangat berbeda dari beberapa virus lainnya seperti virus SARS-CoV dan MERS-CoV. Homologi antara COVID-19 memiliki karakteristik yang sama denha DNA coronavirus yang terdapat dikelelawar-SARS yakni memiliki kemiripan lebih dari $85 \%$ apabila di kultur dengan vitro. covid-19 dapat di temui didalam sel epitel pernapasan manusia setelah 96 jam. Sementara itu untuk mengisolasi dan mengkultur vero E6 dan Huh-7 garis sel dibutuhkan waktu sekitar 6 hari. Paruparu merupakan organ yang akan sangat terdampak oleh Covid-19, sebab virus tersebut menyerang sel

${ }^{2}$ Laporan tahunan Komisi Pemberantasan Korupsi tahun 2019. . 123 
inang melalui enzim ACE2, yang paling melimpah di sel alveolar tipe II paru-paru. Virus ini menggunakan glikoprotein permukaan khusus, yang disebut dengan spike, lalu akan terhubung dengan ACE2 kemudian masuk kedalam sel inan ${ }^{3}$. Kepadatan ACE2 di setiap jaringan akan memiliki korelasi dengan tingkat keparahan penyakit di jaringan tersebut serta terdapat pendapat beberapa ahli yang mengatakan bahwa penurunan aktivitas ACE2 akan bersifat protektif. Sehingga perkembangan penyakit alveolar, akan memungngkinkan terjadi kegagalan pernapasan bahkan memungkinkan terjadi kematian ${ }^{4}$.

Munculnya wabah Covid-19 membuat aktifitas masyarakat Indonesia menjadi tidak normal bahkan di seluruh dunia, terutama aktifitas ekonomi yang mengakibatkan banyak kerugian yang di alami, harga saham anjlok, karyawan dirumahkan, PHK serta pendidikan dari jarak jauh harus di laksanakan. kondisi Pandemi Covid-19 ini, pemerintah banyak sekali menggelontorkan dana untuk korban yang tertimpa, penanganan covid-19 dan pemulihan ekonomi, melalui Perpu pemerinta mengucurkan dana tambahan belanja APBN 2020 untuk menangani Covid-19 dengan total sebesar $\mathrm{Rp}$ 405,1 Triliun, jumlah tersebut dengan rinciaan yakni $\mathrm{Rp} 75$ triliun belanja dibidang kesehatan, Rp 70,1 Triliun intensitas perpajakan dan stimulus Kredit Usaha akyat (KUR), dan Rp 150 Triliun untuk melakukan biaya program

${ }^{3}$ Letko M, Marzi A, Munster V, Functional assessment of cell entry and receptor usage for SARS-CoV-2 and other lineage B betacoronaviruses. Nature Microbiology: 18.2020. doi: 10.1038/s41564-020-0688-y

${ }^{4} \mathrm{Xu} \mathrm{H}$, Zhong L, Deng J, Peng J, Dan H, Zeng X, et al. (February 2020). "High expression of ACE2 receptor of 2019-nCoV on the epithelial cells of oral mucosa". International Journal of Oral Science. 12 (1) 2020. 8 doi:10.1038/s41368-0200074-x memulihkan keadaan ekonomi secara nasional. ${ }^{5}$.

Dana yang telah di keluarkan oleh pemerintah tersebut dengan nominal yang sangat besar perlu untuk di awasi pelaksanaannya agar benarbenar digunakan untuk penanganan yang terdampak Covid-19. Untuk itu para pejabat yang berwenang untuk mengambil kebijakan diharapkan mampu membuat kebijakan yang tepat dalam penyaluran dana tersebut agar tidak di salah gunakan dana tersebut untuk kepentingan pribadi. Namun tidak menutup kemungkinan dana tersebut digunakan disalahgunakan untuk kepentingan pribadi.

Mengingat penelitian mengenai pidana mati bagi pelaku korupsi pernah dilakukan oleh beberapa penulis sebelumnya, seperti: 1) penelitian yang dilakukan oleh Zaid Alfauza Marpaung di tahun 2019 penelitian ini berfokus pada penjatuhan pidana mati bagi pelaku korupsi khususnya dalam perspektif hukum pidana islam ${ }^{6} .2$ ) penelitian yang dilakukan oleh khaeron Sirin yang berfokus pada penerapan pidana mati bagi tindak pidana Korupsi dengan pendekatan Teori Maqashid AlSyari'ah di tahun $2013^{7}$

Berdasarkan penelitian sebelumnya telah dilakukan, maka ditemui perbedaan yang akan menjadi fokus penelitian ini, walaupun tema yang diambil memiliki keterkaitan tentang pidana mati, namun penelitian ini menekankan padapelaku tindak

5 Hukum Online, Jerat pidana mati jika menyalahgunakan dana Covid-19. di akses pada 23 Agustus 2020, Pukul 18.00 WIB

6 Zaid Alfauza Marpaung, Kebijakan Hukuman mati Bagi Pelaku Tindak pidana Korupsi dalam Perspektif Hukum Pidana Islam, Sumatera Utara: jurnal Ilmiah Advokasi, Vol. 07. No. 01. 2019

7 Khaeron Sirin, penerapan hukuman Mati bagi Pelaku Kejahatatn Korupsi di Indonesia :Analsisis Pendekatan Teori Maqashid al-Syariah, Istinbath, Jurnal hukum Islam, Vol 12, No 1, Juni 2013 
Pidana mati di masa Pandemi Covid-19 dapat dijatuhi Pidana Mati. Maka dapat dirumuskan permasalahan yang perlu dikaji, yaitu: 1) bagaimana kebijakan Kriminal dalam menanggulangi tindak pidana Korupsi?, 2) Apakah tindak pidana korupsi dapat dijatuhi pidana mati?. Tujuan penelitian ini adalah untuk dapat mengetahui terkait 1) kebijakan criminal dalam menanggulangi tindak pidana korupsi, 2) untuk mengetahui penjatuhan pidana mati bagi pelaku tindak pidana korupsi.

\section{B. METODE PENELITIAN}

Metode penelitian -yang di gunakan dalam penulisan tulisan ini yakni menggunakan yuridis normatif dengan menggunakan pendekatan perundang-undangan. Metode penelitian yuridis normatif merupakan suatu penelitian hukum dari perspektif internal dengan menggunakan objek penelitian norma hukum. ${ }^{8}$ Sumber penelitian dalam tulisan ini yakni menggunakan data yang diperoleh dengan cara menelaah bahan hukum primer, yaitu peraturan perundangundangan yang berkaitan dengan penelitian ini ,dan bahan hukum sekunder yakni berupa doktrin hukum atau teori hukum yang nantinya diperoleh dari bebrapa literatur hukum dan penelitian ilmiah. Kemudian penulis akan mengkaitkan dengan permasalahan yang menjadi pokok bahasan yakni Pidana Mati terhadap Pelaku Tindak Pidana Korupsi Di Masa Pandemi Covid 19.

Penelitian ini ditulis dengan menggunakan metode penulisan kualitatif. Metode penulisan kualitait ini dengan cara mengurai data kedalam kalimat hingga menjadi sebuah paragraph yang teratur, logis dan runtut (sistematis), dan efektif. Kemudian di

${ }^{8}$ I Made Pasek Diantha, Metodologi Penelitian Hukum Normatif dalam Justifikasi Teori Hukum, (Jakarta: Prenada Media Group,2016), 12 ambil kesimpulan secara deduktif sebagai jawaban atas kebijakan kriminal dalam menanggulangi tindak pidana korupsi dan penjatuhan pidana mati bagi pelaku tindak pidana korupsi.

\section{HASIL DAN PEMBAHASAN \\ 1. KEBIJAKAN KRIMINAL DALAM MENANGGULANGI TINDAK PIDANA KORUPSI}

Pengertian kebijakan kriminal (criminal policy) adalah suatu usaha rasional dan terorganisir dari suatu masyarakat untuk menanggulangi kejahatan, dimana definisi ini di ambil dari Marc Ancel yang merumuskan sebagai "the rational organization of control crime by society"

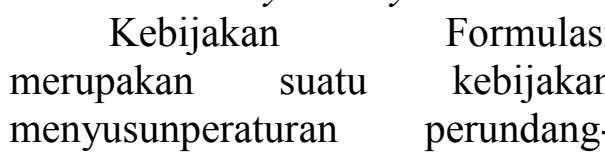
undangan, serta bagian yang integral dari suatu kebijakan hukum pidana (penal police). Prof Sudarto berpendapat bahwa beberapa maksud dari kebijakan kriminal dalam arti sempit, yakni suatu keseluruhan asas atau metode yang dijadikan dasar dari reaksi terhadap suratu pelanggaran hukum berupa pidana adalah yakni sebagai berikut: ${ }^{10}$

a. Apabila dilihat dari arti yang sempit maka Seluruh fungsi dari aparat penegak huukum yang di dalamnya termasuk lembaga kepolisian, lembaga kejaksaan dan lembaga pengadilan

b. Dilihat secara luas, telah dikemukakan menurut pendapat Jorgen Jopsen, yakni

9 Arief, Barda Nawawi. Bunga Rampai Kebijakan Hukum Pidana, (Bandung: Citra Aditya Bakti 1999), 2

10 Febrikusuma, Thomas W., Soponyono, Eko., \& Purwoto. "Kebijakan Hukum Pidana Dalam Upaya Penanggulangan Tindak Pidana Gratifikasi Di Kabupaten Blora". Diponegoro Law Journal, Vol.5, (No.2), 2016. pp. 1-11 
suatu keseluruhan kebijakan, akan dilakukan melalui peraturan perundang-undangan serta badan badan resmi lainnya dengan tujuan menegakkan suatu norma yang sentral dari masyarakat.

G Peter Hoefnagels menyatakan pendapat yaitu "criminal poliy is the rational organization of the social reactions to crime" dan lebih lanjut uga G. Peter Hoefnagels berpendapat mengenai definisi berkenanan dengan kebijakan kriminal yaitu:

1) Criminal Policy is the science of response (kebijakan kriminal merupakan suatu ilmu mengenai reaksi untuk mengadapi kejahatan).

2) Criminal Policy is the science of preventions (kebijakan kriminal merupakan suatu ilmu dalam menanggulangi suatu kejahatan)

3) Criminal policy is a the science of designating human behaviour as criminal (kebijakan kriminal merupakan suatu kebijakan dalam menyusun tingkah laku manusia sebagai penanggulangan kejahatan).

4) Criminal Policy is a rational total of response to crime (kebiajakn kriminal merupakan suatu reaksi terhadap kejahatan yang rasional) ${ }^{11}$

Penanggulangan Kejahatan pada hakikatnya adalah suatu bagian integral dari upaya perlindungan masyrakat (social defence) dan upaya untuk mencapai kesejahteraaan masyarakat (social walfare). Demikian itu maka, dapat dikatakan bahwa tujuan utama dari

${ }^{11}$ G. Peters Hoefnagels, The Other Slide of Criminology (An Inversion of the Consecpt of crime), (Kluwer-Duventer, Holland, 1969), 57 politik kriminal yakni perlindungan masyarakat untuk mencapau kesejahteraan masyarakat. Oleh karena itu dikemukakan bahwa tujuan akhir dari politik kriminal yakni usaha perlindungan kepada masyarakat untuk mencapai kesejahteraan masyarakat. Perumusan tujuan politik criminal demikian itu dinyatakan di dalam salah satu laporan kursus latihan ke-34 oleh UNAFEI di Tokyo bahwa " most of group members agreed some discussion that protection of the society could be accepted as the final goal of criminal policy, olthough not be ultimate aim of society, wich might perhaps be described by terms like happiness of citizens, a wholesome and cultural living, social walfare or equality".

Dikatakan bahwa politik kriminal pada hakikatnya adalah bagian integral dari politik sosialyang bertujuan untuk melindungi masyarakat dan kesejahteraan masyarakat, untuk itu pengaturan pengenai memberantas tindak pidana korupsi juga merupakan bagian terhadap upaya untuk mensejahterakan masyarakat.

Menurut G P. Hoefnaels mengemukakan beberapa upaya penanggulangan kejahatan, yaitu: penegakan hukum pidana (criminal law aplications); pencegahan tanpa pidana (prevention without punismenst); mempengaruhi pandangan masyarakat tentang kejahatan; dan pemidanaan melalui media masa (insfluencing views of society on criminal and punishment) ${ }^{12}$.

Dua masalah pokok dalam suatu kebijakan kriminal yang mengggunakan sarana penal

12 Arief, Barda Nawawi. Bunga Rampai Kebijakan Hukum Pidana, (Bandung: Citra Aditya Bakti, 2002), 1 
(hukum pidana) adalah masalah penentuan: ${ }^{13}$

1) Bahwa Perbuatan apa yang akan dijadikan tindak pidana, dan;

2) Sanksi apa yang sebaiknya diberikan kepada pelanggar.

Menganalisis dua masalah pokok tersebut maka tidak dapat dilepaskan dari konsep integral antara kebijakan kriminal dengan kebijakan sosial atau dengan kebijakan pembangunan national, hal ini merupakan pemecahan masalah-masalah tersebut harus diarahkan untuk mencapai tujuantujuan tertentu dari kebijakan sosial politik yang telah di tetapkan dengan menggunakn pendekatan yang berorientasi pada kebijakan (policy oriendted appoarch. Dalam menetapkan suatu perbuatan merupakan suatu tindak kriminal atau bukan, maka diperlukan kriteria umum diantaranya:

1) Apakah perbuatan tersebut tidak di inginkan atau tidak disukai oleh masyarakat karena dianggap merugikan, atau dapat merugikan, mendatangkan korban atau dapat medatangkan korban.

2) Apakah biaya utuk mengkriminalisasi akan imbang dengan capaian hasil, artinya cost pembuatan undang-undang, pengawasan dan penegakan hukum, serta beban yang di pikul oleh korban, pelaku kejahatan itu sendiri haruu seimbang dengan situasi tertib hukum yang akan dicapai.

3) Apakah akan menambah beban para aparat penegak hukum yang tidak seimbang dengan nyata-nyatanya tidak dapat di emban oleh kemampuan yang

\footnotetext{
${ }^{13}$ Ibid. Hllm. 29
}

dimiliki aparat penegak hukum.

4) Apakah perbuatan tersebut akan menghambat atau menghalangi cita-cita bangsa, sehingga merupakan bahaya bagi keseluruhan masyarakat

Apabila dicermati didalam memberantas tindak pidana korupsi maka terdapat tiga usulan yang di ajukan oleh para ahi hukum maka diperlukan hukuman yang secara langsung memberikan efek jera kepada para koruptor yakni: Hukuman mati, Pemiskinan dan pembuktian terbalik ${ }^{14}$. Seperti halnya pendapat Mahfud MD yang mengatakan bahwa hukuman mati bagi koruptor benar-benar dilaksanakan ${ }^{15}$. Dikuatkan oleh pernyataan Basaria Panjaitan yang menyatakan bahwa mendukung hukuman mati bari para koruptor agar, memberikan efek jera, maka demikan itu kepada pelaku tindak pidana korupsi (TPK) secara khusus dan tertentu maka harus dijatuhi pidana mati.

\section{PENJATUHAN PIDANA MATI BAGI PELAKU TINDAK PIDANA KORUPSI DI MASA PANDEMI COVID-19}

Eksistensi hukuman pidana maati di indonesia saat ini masih eksis dan dopertahankan keberadaannya, baik di untuk tindak pidana umum maupun tindak pidana khusus. Pidana mati terhadap tindak pidana khusus diantaranya ialah tindak pidana korupsi, Korupsi merupakan kejahatan yang sangat luar biasa (extraordinary crime), memiliki sifat yang sistematis dan endemik dan berdampak luas (systemic and qidespread) sehingga

14 Etty Indriati, Pola dan Akar Korupsi, (Jakarta: PT Gramedia, 2014) ,30

http://nasional.kompas.com/read/2014/02/28/02171 02/Mahfud.MD.Koruptor.Layak.Dihukum.Mati 
penanganan yang dilakukan memerlukan upaya yang komprehensif dan penjatuhan hukuman yang dilakukan harus menimbulkan efek jera, demikian itu menjadikan pidana mati terdap tindak pidana korupsi masih dipertahankan sampai saat ini.

Penjatuhan pidana mati di dalam hukum positif tidak pernah dirumusakan secara tunggal, padahal pidana mati merupakan pidana pokok yang saat ini digunakan di hukum positif, pelaksanaan pidana mati selalu di rumuskan secara alternatif atau upaya terakhir. Didalamundang-undang nomor 31 tahun 1999 pidana mati dapat di jatuhkan kepada pelaku berdasarkan Pasal 2 menjelaskan bahwa koruptor dijatuhi pidana mati dengan keadaan tertentu. Terdapat pemberatan di rumusan limitatif tersebut agar pidana mati dapat di jatuhkan.

Menurut "Pasal 2 ayat (1 bahwa setiap orang yang secara melawan hukum perbuatan memperkaya diri sendiri atau orang lain suatu korporasi yang dapat merugika keuangan Negara atau perekonomoian Negara, dipidana dengan pidana penjara seumur hidup atau pidana penjara paling singkat 4 (empat) tahun dan paling lama 20 (dua puluh) tahun dan denda paling sedikit RP. 200.000.000,00 (dua ratus juta rupiah) dan paling banyak $R p$. 1.000.000.000,00 (satu milyar rupiah)". "Ayat (2) dalam hal tindak pidana korupsi sebagaimana dimaksud dalam ayat (1) dilakukan dalam keadaan tertentu, pidana mati dapat dijatuhkan".

Berdasarkan penjelasan pasal 2 bahwa yang dimaksud keadaan tertentu dalam ketentuan ini dimaksud sebagai pemberatan bagi pelaku tindak pidana korupsi apabila tindak pidana tersebut dilakukan pada waktu Negara dalam keadaan bahaya sesuai dengan undangundang yang berlaku, pada waktu terjadi bencana alam nasional, sebagai pengulangan tindak pidana korupsi, atau pada waktu Negara dalam keadaan krisis ekonomi dan moneter.

Penjelasan mengenai Pasal 2 ayat (1) yang telah di batalkan oleh Mahkamah Konstitusi dengan terbitnya Putusan MK Nomor 003/PUUIV/2006 pada 24 Juli 2006, yang menyatakan bahwa: Penjelasan didalam Pasal 2 ayat (1) Undangundang Republik Indonesia Nomor 31 tahun 1999 tentang Pemberantasan Tindak Pidana korupsi sebagaimana diubah dengan Undang-Undang Nomor 20 Tahun 2001 tentang Perubahan Atas Undang -Undang Nomor 31 Tahun 1999 tentang Pemberantasan Tindak Pidana Korupsi (Lembaran Negara Republik Indonesia Tahun 2001 Nomor 134, Tambahan Lembaran Negara Republik Indonesia Nomor 4150) sepanjang frasa yang berbunyi: bahwa maksud dari secara melawan hukum didalam pasal ini meliputi perbuatan melawan hukum dalam arti formiil ataupun arti materiil, yaitu walaupun suatu perbuatan yang dilakukan tidak diatur didalam Undang-undang, namun jika suatu tersebut telah dianggap sebagai perbuatan yang tercela dan tidak sesuai dengan rasa keadilan atau normanorma didalam masyarakat, maka suatu perbuatan tersebut dapat dijauhi dipidana", tidak mempunyai kekuatan hukum mengikat". 16

Bahwa dengan adanya rumusan tindak pidana korupsi sebagai delik formiil, seharusnya terdapat kerugian negara atau kerugian perekonomian negara tidak harus terjadi, karena yang dimaksud dengan delik formiil adalah delik yang dianggap telah

16 Putusan MK Nomor 003/PUU-IV/2006 tanggal 24 Juli 2006. 
selesai dengan dilakukannya tindakan yang dilarang dan diancam dengan hukuman oleh undang undang. ${ }^{17}$ Demikian ini dimaksudkan untuk orang dinyatakan bersalah telah melakukan tindak pidana korupsi seperti yang ditentukan dalam Pasal 2 ayat (1), tidak perlu adanya alat-alat bukti untuk membuktikan bahwa memamng telah tejadi kerugian negara atau perekonomian Negara.

Keadaan tertentu disini dijelaskan diantaranya ialah bencana nasional ayau keadaan darurat. Berdasarkan penejalasan ayat 92) dalam keadaan tertentu orang yang melakukan tindak pidana korupsi dapat di hukum pidana mati sesuai dengan ketentuan, demikian itu penyalahgunaan dana covid-19 dapat dikategorkian sebagai keadaan tertentu sehingga pelaku tindak pidana korupsi dana covid-19 dapat di jatuhi pidana mati.

Terdapat beberapa kelamahan yang bisa di identifikasi di dalam UU Tindak Pidana Korupsi,yakni berkaitan dengan penjatuhan Pidana Mati terhadap pelaku Tindak Pidana Korupsi :

1. Pidana mati sebagai pemberatan pidana, hanya akan diancam untuk Tindak Pidana Korupsi tertentu sebagaimana menurut pasal Pasal 2 ayat (1), yakni melakukan perbuatan memperkaya diri sendiri /orang lain/koorporasi secara melawan hukum. demikian itu tidak akan ditujukan kepada semua bentuk Tindak Pidana Korupsi, padahal menurut penjelasan umum dijelaskan berkenaan tujuan membuat Undang-Undang Nomor 31 tahun 1999 ini (sebagai pengganti Undang-Undang Nomor 3 tahun 1971) yang sebagai Upaya Pemerintah dalam memberantas tindak pidana korupsi. Maka

17 R. Wiyono, Pembahasan UndangUndang Pemberantasan Tindak Pidana Korupsi, (Jakarta: Sinar Grafika, 2008), 28 diancam dengan pidana mati sebagai pemberatan pidana ${ }^{18}$. Menurut pasal 2 ayat (2), pidana mati merupakan suatu pemberatan pidana terhadap delik didalam Pasal 2 ayat 1 yang diancam dengan pidana seumur hidup atau dengan penjara 20 tahun. Dalam Undang-Undang No. 31/1999 Jo Undang-Undang No. 20/2001, tindak pidana korupsi yang diancam dengan pidana seumur hidup atau maksimun penjara 20 tahun tidak hanya terdapat dalam pasal 2, tetapi terdapat juga dalam Pasal 3 yang berbunyi: "penyalagunaan kewenangan /kesempatan /sarana karena jabatan atau kedudukan". Kemudian Pasal 12: Penerimaan suap (suap pasif) oleh pegawai negeri/penyelenggara Negara, Hakim, dan Advokat. Merupakan suatu kejanggalan kalau pidana mati hanya diancamkan terhadap pasal 2 Sedangkan dalam pandangan masyarakat dan dilihat dari hakikat korupsi sebagai delik jabatan, perbuatan "menyalagunakan kewenangan jabatan/ kedudukan" (Pasal 3) dan "penerimaan suap oleh pegawai negeri /penyelenggara Negara, hakim dan advokat (pasal 12) dirasakan lebih tercela dari pada memperkaya diri" pasal (2); setidak-tidaknya harus dipandang sama berat, dan oleh karenanya juga layak untuk diancam dengan pidana mati, terlebih delik penyuapan justeru paling menonjol dalam berbagai kasus korupsi selama ini.

2. Kelemahan selanjutnya berkaitan dengan keadaan tertentu dengan alas an suatu pemberatan pidana

${ }^{18}$ Barda Nawawi Arief, 2012. Pidana Mati Perspektif Global, Pembaharuan Hukum Pidana Dan Alternatif Pidana Untuk Koruptor, Cet. 1. Semarang: Pustaka Magister Ilmu Hukum. 
dapat dijatuhi pidana mati. Formulasi Undang-undang mengenai keadaan tertentu akan menjadi salah satu alasan pemberatan pidana pada umumnya dirumuskan secara tegas dalam perumusan delik yang bersangkutan. Alasan keadaan tertentu mrngrnsi pidana mati terhadap pelaku korupsi dijelaskan pada pasal 2 Ayat 2 UndangUndnag Nomor 31 tahun 1999, dengan kelemahan belum mengatur secara tegas apakah Pidana mati dapat jatuhkan padahal tindak Pidana korupsi sudah merupakan bencana dan merupakan ancaman bagi negara yang ingin berkembang dan terkait dengan penjelasan keadaan tertentu: dapat digambarkan sebagai berikut:

Keadaan tertentu berdasarkan Undang-Undangg nomor 31 tahun 1999, Alasan kondisional apabila dilakukan:

1. Pada saat negara sedang keadaanBahaya berdasarkan ketetapanperaturan perundang-undangan;

2. Pada saat terjadi bencana nasional atau;

3. Sedang dalam krisis ekonomi

Akan tetapi pemerintah mengeluarkan Perppu nomor 1 tahun 2020 yang dapat mengakibatkan lemahnya penegakan hukum terhadap tindak pidana korupsi. Dimana di dalam Perppu tersebut terdapat kebijakan tentang keuangan dan stabilitas sistem keuangan untuk menangani Covid-19 yang terdapat di dalam Pasal 27 ayat 1 Perppu nomor 1 tahun 202 yang berbunyi: "biaya yang dikeluarkan pemerintah dan/atau lembaga anggota KSSK dalam rangka pelaksanaan kebijakan pendapatan
Negara termasuk kebijakan di bidang perpajakan, kebijakan belanja Negara termasuk kebijakan di bidang keuangan daerah, kebijakan pembiayaan, kebijakan stabilitas sistem keuangan, dan program pemulihan ekonomi nasional, merupakan bagian dari biaya ekonomi utuk penyelamatan dari krisis dan bukan merupakan kerugian Negara"

- Ayat (2) "anggota KSSK, Sekretaris KSSK, anggota sekretaris KSSK, dan pejabat atau pegawai kementrian keuangan, Bank Indonesia, Otoritas jasa Keuangan, serta lembaga Penjamin Simpanan, dan Pejabat lainnya, yang berkaitan dengan pelaksanaan peraturan pemerintah Pengganti UndangUndang ini, tidak dapat di tuntut baik secara perdata maupun secara pidana jika dalam melaksanakan tugas didasarkan pada iktikad baik dan sesuai dengan ketentuan peraturan perundang-undangan".

Menurut Romli Atmasasmita pelaku tindak pidana korupsi tidak dapat berlindung di dalam pasal tersebut hal ini disebabkan pasal tersebut kontradiktif terhadap UndangUndang Tindak Pidana Korupsi dan perubahannya. Demikian ini yang mengakibatkan seperti aparat penegak hukum tidak dapat melakukan penyelidikan dan penyidikan terhadap kasus korupsi tersebut. Di dalam substansi pasal 27 ayat 1menimbulkan kebingungan sebab menyatakan bahwa biaya yang dikeluarkan pemerintah untuk penanganan covid-19 bukan suatu kerugian Negara. ${ }^{19}$

Sementara Peneliti Hukum Indonesia Corruption Watch (ICH) Kurnia Ramadhana Menilai Perppu Nomor 1 Tahun 2020 ini memang tidak tertalalu jelas, secara spesifik di

19 Anisa Mufida, Polemik Pemberian Hukuman Mati Pelaku Korupsi di tengah pendemi Covid-19. Adalah Buletin hukum \& Keadilan. Vol 4 Nomor 1. 2020, 225 
dalam Pasal 27, dikarenakan terdapat kesan agar kebal terhadap hukum baik dari jeratan pidana maupun terjerat secara perdata. Akan tetapi dengan adanya frasa "itikad baik" didalam pasal 27 ayat (2) menjadi ukuran/batasan ketika pejabat Negara tidak memenuhi kriteria pengelolaan keuangan/anggaran penanggulangan covid-19, artinya Undang-Undang pemberantasan tipikor tetap dapat menjerat para pelaku korupsi yang melakukan penyelahgunaan wewenang dan mengambil keuntungan di tengah pandemic Covid-19.

Sehingga jika melihat frasa "kerugian Negara" yang tertuang di dalam Pasal 27 ayat (1) Perppu Nomor 1 tahun 2020 mengacu pada penggunaan dana Anggaran Pendapatan Belanja Negara (APBN), sehingga ketika dugaan tindak pidana korupsi menimbulkan kerugian Negara, regulasi yang tepat adalah menggunakan Undang-Undang tindak Pidana Korupsi. Dengan demikian berarti bahwa pelaku tindak pidana korupsi dana Pandemi Covid-19 dapat di pidana sesuai dengan undang-undang Nomor 31 tahun 1999.

\section{KESIMPULAN}

Berdasarkan uraian dan pembahasan di atas maka dapat di simpulkan bahwa 1)kebijakan kriminal merupakan bagian dari upaya untuk menanggulangi kejahatan tindak pidana korupsi yang bertujuan untuk mensejahterakan masayarakat dan melindungi masyarakat dari tindak pidana korupsi yang dilakukan secara sistemik yang dapat menghancurkan sektor pembangunan nasional 2) Penjatuhan pidana mati dapat dilakukan kepadan para pelaku koruptor yang melakukan korupsi dana Pandemi Covid-19 hal tersebut didasarkan pada Undang-Undang nomor 31 tahun 1999 tentang Komisi Pemberantasan Korupsi Pasal 2 yang menjelaskan penjatuhan pidana mati dapat dilakukaan apabila dalam keadan tertentu, keadaan tertentu dalam hal ini Pandemi Covid-19, karena termasuk keadaan dimana Negara sedang mengalami bencana. Sehingga dana yang dikeluarkan dan telah di anggarkan harus dilaksanakan untuk menangani Pandemi tidak untuk menguntungkan pribadi, apabila hal itu digunakan untuk kepentingan pribadi maka aparat penegak hukum diperbolehkan untuk menjatuhi pidana mati dengan pemberatan keadaan tertentu.

\section{DAFTAR PUSTAKA}

\section{Buku}

Arief, Barda Nawawi. Bunga Rampai Kebijakan Hukum Pidana, Bandung: Citra Aditya Bakti, 2002.

Arief, Barda Nawawi. Pidana Mati Perspektif Global, Pembaharuan Hukum Pidana Dan Alternatif Pidana Untuk Koruptor, Cet. 1. Semarang: Pustaka Magister Ilmu Hukum. 2012

Indriati, Etty, Pola dan Akar Korupsi, Jakarta: PT Gramedia, 2014.

G. Peters Hoefnagels, The Other Slide of Criminology (An Inversion of the Consecpt of crime), KluwerDuventer, Holland, 1969

I Made Pasek Diantha, Metodologi Penelitian Hukum Normatif dalam Justifikasi Teori Hukum, Jakarta: Prenada Media Group,2016

Laporan Komisi Pemberantasan Korupsi, sepanjang tahun 2019

Wiyono R, Pembahasan Undang-Undang Pemberantasan Tindak Pidana Korupsi, Jakarta: Sinar Grafika, 2008

\section{Jurnal}

Anisa, Mufida , Polemik Pemberian Hukuman Mati Pelaku Korupsi di tengah pendemi Covid-19. Adalah 
Buletin hukum \& Keadilan. Vol 4 Nomor 1. 2020.

Febrikusuma, Thomas W., Soponyono, Eko., \& Purwoto. (2016). "Kebijakan Hukum Pidana Dalam Upaya Penanggulangan Tindak Pidana Gratifikasi Di Kabupaten Blora". Diponegoro Law Journal, Vol.5, (No.2), pp. 1-11

Letko M, Marzi A, Munster V (2020). "Functional assessment of cell entry and receptor usage for SARS-CoV-2 and other lineage $B$ betacoronaviruses". Nature Microbiology: 1-8. doi:10.1038/s41564-020-0688-y

Marpaung, Zaid Alfauza, Kebijakan Hukuman mati Bagi Pelaku Tindak pidana Korupsi dalam Perspektif Hukum Pidana Islam, Sumatera Utara: jurnal Ilmiah Advokasi, Vol. 07. No. 01. 2019

Sirin, Khaeron, penerapan hukuman Mati bagi Pelaku Kejahatatn Korupsi di Indonesia : Analsisis Pendekatan Teori Maqashid al-Syariah, Istinbath, Jurnal hukum Islam, Vol 12, No 1, Juni 2013
Xu H, Zhong L, Deng J, Peng J, Dan H, Zeng X, et al. (February 2020). "High expression of ACE2 receptor of 2019-nCoV on the epithelial cells of oral mucosa". International Journal of Oral Science. 12 (1): 8. doi:10.1038/s41368-020-0074-x

\section{Undang-Undang}

Undang-Undang Nomor 31 tahun 1999 tentang Komisis Pemberantasan Korupsi Perppu No 1 Tahun 2020

Putusan MK Nomor 003/PUU-IV/2006 tanggal 24 Juli 2006.

\section{Internet}

http://nasional.kompas.com/read/2014/02/2 8/0217102/Mahfud.MD.Koruptor.Layak.D ihukum.Mati di akses pada 23 Agustus 2020

Hukum Online, Jerat pidana mati jika menyalahgunakan dana Covid-19. di akses pada 23 Agustus 2020 , Pukul $18.00 \mathrm{WIB}$ 